\title{
La resematización del mito del viaje en lo audiovisual
}

\section{Re semanticize myth of the voyage in audiovisual}

\section{Julieta Sepich}

Universidad de Buenos Aires

julietasepich@gmail.com

Resumen Dentro del nuevo paradigma que nos habla no ya de la dicotomía entre realidad y ficción, sino de la instauración de mundos posibles, la producción audiovisual aparece como un lugar desde el que construir uno de ellos. La necesidad de resemantizar aparece entonces como un intento de detener la idea de huir del mito como forma de creación original.

El abismo de la hoja en blanco, la duda dentro de la sala de montaje, y el dilema que surge de la necesidad de respetar el original script a la hora de ir al set de filmación, parecen ser el gran conflicto del realizador audiovisual; y de alguna manera forman parte de la problemática del creador y su producción artística.

La creatividad es entonces la espada que blanden los individuos para perpetuar esa huida que pareciese imposible.

Palabras clave Matriz cultural, sentido, gramática audiovisual, viaje.

\begin{abstract}
Within the ideas presented in the "New Paradigm" which not only expresses the dichotomy between fiction and reality but sets up new "possible worlds", audio-visual production emerges as a space to construct in. A need to give new meaning tranforms into an attempt to stop the idea of running away from myth as the unique form of original creation.

The abyss in front of the blank page, the doubts inside the editing room and also the need to respect the "original' script once on set, seem to be the major problems facing the audio visual artist. Somehow these issues are part of the problematic of the creator and his artistic production.

The creativity was at the time the sword that the individuals brandish to perpetuate this flight that seemed to be impossible.
\end{abstract}

Keywords Cultural matrix, sense, audiovisual grammar, trip 


\section{El viaje como idea inicial e iniciática. El sentido como motor de búsqueda}

Asomándose al mundo de la creación audiovisual pareciese que todo se reduce a qué y cómo contar. El abismo de la hoja en blanco, la duda dentro de la sala de montaje y el dilema que surge de la necesidad de respetar el guión original a la hora de ir al set de filmación, parecen ser el gran conflicto del realizador audiovisual; Y que -de alguna manera- forman parte de las problemáticas del artista.

Pero qué es lo que sucede antes; Qué nos mueve a contar historias; Qué nos acerca a un lenguaje que se construye con luz, tiempo y espacio. Qué es lo que imprime un tono, un género, un color o cuerpo en nuestra necesidad de expresión.

Por qué encontramos en la producción audiovisual - o no- ciertas marcas, ciertas recurrencias y repeticiones en la utilización de los significantes o en la forma que cristaliza el tema.

Nos vemos entonces como meros cambiadores de figuritas -como lo señala María de los Ángeles Gonzalez en sus seminarios sobre matrices culturalesseleccionando y combinando dentro de un tablero vasto, pero finito.

Entonces, cómo inscribo la noción de original, de nuevo en la creación artística.

Lo original, lejos de permanecer ajeno a lo pre-existente, rastrea la fuente en sus múltiples apariciones. El pensamiento original es el nacimiento de una forma, es la re significación de esa fuente palpitando. La innovación actualiza así, de una manera diáfana, el origen.

Podemos convenir que existe un pensamiento visual, un pensamiento que se instala como desplazamiento a las formas. Es, en ocasiones, la razón fundante de patrones hegemónicos. lo audiovisual aparece como una necesidad imperiosa de fundar formas a modo de rito iniciatico.

Si pensamos en el tablero dispuesto frente a nosotros para abismarnos a la creación, encontramos lo que Jordi Balló indaga tanto en La semilla inmortal, como en Imágenes del silencio; La existencia de matrices culturales que aparecen como marcas cristalizadas, promueve una lectura colectiva consensuada de las formas y de las narraciones que se actualizan, pero, pese a ello, aparecen como trama invisible en nuestra producción artística.

Estas matrices están relacionadas con el lenguaje oral y escrito, con el pensamiento visual o motivos visuales, con los juegos, y con los mitos o historias fundantes.

Para instalar definitivamente el sesgo que propone este trabajo es que intento relacionar la producción audiovisual con las matrices vinculadas a los mitos, en particular con los mitos de viajes, con aquellas historias que subyacen en la historia 
del cine, y que emergen y se actualizan en diversos significantes de la imagen audiovisual.

Entonces: Cómo pensar en lo nuevo como algo que sólo es una actualización de un relato arcaico. Cómo escapar de la repetición de un relato que no reconocemos como - visiblemente- propio.

El relato audiovisual construye un universo de significantes que desplazan a imagen, a sonido, a tiempo, a espacio, todo aquello que se traspone del mundo de las palabras, del discurso.

El lenguaje audiovisual re-configura el mundo que se naturaliza de un modo misterioso. Los relatos míticos aparecen entonces, como grandes condensaciones de sentido. La necesidad de historizar nuestra existencia se desplaza en la creación subjetiva al lugar de la re-significación de esas matrices. idea de un referente que nos precede, genera en el creador, una noción de realidad. Un grado cero que formula sus visiones de manera inconsciente.

El emblemático artista del surrealismo Salvador Dali dispara:

Algún día se tendrá que admitir oficialmente que lo que hemos bautizado como realidad es una ilusión mayor que el mundo de los sueños (...) Hay que provocar sistemáticamente confusión, esto da rienda suelta a la creatividad. (... ) Todo lo que es contradictorio da lugar a la vida (...) el deseo de sobrevivir y el miedo a la muerte son sentimientos artísticos. ( Dalí, 2003 )

Pedir prestada su visión sirve de trampolín para poner en crisis la necesidad imprescindible del artista y su producción,: la búsqueda y construcción de sentido.

En palabras de Charles Chaplin: "La vida no tiene sentido, hay que darle uno"

\section{Un viaje de ida o Las aventuras de Jason}

Qué sería del cine de aventuras sin el objeto maravilloso; Ese vellocino de oro, que encierra "la espiritualidad y la pureza pero que genera codicia y trivialidad" (Balló- Pérez, 1995) situado en lo alto del árbol de la vida y custodiado por un dragón que debe ser sometido.

Y otra vez el origen, donde este héroe del viaje de aventuras encuentra su rito inicial en la primera gesta mítica, la de Jasón y los Argonautas (Apolonio de Rodas, ed.1995) el gran poema épico donde encontramos la fuente argumental de todos los viajes que parten a la busca de un tesoro.

Es así que el objeto del tesoro, como encargo, mediado por una serie de peripecias; ha sido en la historia del cine muchas veces la razón misma del género. 
El verosímil del viaje de aventuras deja vislumbrar esa diáfana fuente que lo construye como el tránsito del héroe con la conquista -como excusa- de un objeto preciado.

Entonces, hasta qué punto el deseo del protagonista devenido en alter ego del espectador no es modelizado por los relatos de origen?

Hasta que punto el trazado del camino como desplazamiento de nuestra existencia no esta previamente diseñado por estas historias fundantes?

Estas marcas a nivel del relato comparten con los significantes propios del cine e inauguran los códigos que se traducen en género.

Asimismo, Indiana Jones, replicado en infinitos héroes que comparten su rito, se lanza a la conquista de este tesoro que luego se refractara en el tránsito de su recorrido, y adoptara ese carácter dual de objeto y a la vez esa condición de maravilloso, que servirá como excusa y fundamento de ese arduo y peripésico viaje.

Esa dialéctica que se reproduce en todos los relatos de aventuras o acción, entre el Bien y el Mal, es siempre traducción de esa condición del objeto deseado y condición de todos los seres que participan en la gesta.

El carácter trivial del objeto perseguido, pone de manifiesto lo que Hitchcock llamaba la teoría del MacGuffin, que aparece como:

un elemento destinado a crear un objetivo primario para los protagonistas, en pocas palabras lo que los personajes buscan. Esta teoría consiste en aceptar el grado de irrelevancia que tiene ese objeto en el significado global del film (...)

El director sabotea cualquier rasgo griálico y sublime que el MacGuffin pudiera contener, e incluso aconseja no atribuirle ninguna importancia simbólica, aunque sea indispensable para que la acción se produzca. (Truffaut, 2003)

El Mal, encarnado en los enemigos del héroe, poseen también una lectura dual, esa que les permite redimirse y dudar en esa lucha contra el Bien (que también lleva su propia contradicción) Aquella que lo hace codiciar bajo cualquier arbitrio ese tesoro.

El héroe de este relato nutre su bondad con el enfrentamiento con el Mal. El Bien y el Mal encapsulado en su piel y la de sus oponentes, muestra solo una de sus caras, pero sin dejar de revelar su dualidad.

La idea de esa dialéctica que produce pares antagónicos, muestra la condición intrínseca del individuo, desdoblada de forma maniquea, donde observamos esta lucha de bandos como diseño polar. 
Pero dentro del relato de origen, las fases ineludibles aparecen recicladas en las transposiciones cinematográficas. El encargo previo, a veces es reemplazado por un trazado caótico y sin metas evidentes, como sucede, por ejemplo, en el viaje de los personajes de Hopper en Easy Ryder donde la road movie se torna existencialista, donde recupera valores aventureros pero originados más por una huida que por un encargo. Y allí se hace evidente la parte central de la trama origen: El viaje accidentado; los aliados en el camino y la necesidad de movimiento como el trayecto dilatado hacia la propia muerte. Héroes que definen su búsqueda hacia la felicidad con un nomadismo que es promesa de una huida sin fin.

Es entonces donde el espacio pasa a cobrar categoría de significante estrella; El espacio como metáfora del transito obsesivo y desorientado del sujeto moderno.

En otros films es el espacio el que aparece como el bando que entroniza al Mal, las películas de ciencia ficción o lo que se llamo cine catástrofe, actualizan esta visión.

Es el espacio también el que desplaza metafóricamente el viaje aventurero como revelación interior, donde el recorrido del héroe tiene como morada final una mirada diferente con relación a su existencia, el camino como viaje hacia su propia geografía.

La propia materialización del film funciona como suprametáfora del camino recorrido; de ese espacio poéticamente conquistado/dominado.

Balló señala, entre otros, al film 2001, Odisea espacial como una actualización del viaje jasónico en una nave uterina lanzado al intento de comprender el universo.

Un viaje exploratorio y contemplativo, que culmina no ya en la conquista de un objeto griálico, sino en una concreción utópica: "un nuevo concepto de humanidad" (Balló- Pérez, 1995)

En este transito las coodernadas se completan con la relación temporal de estos recorridos. El tiempo como muestra de la duración y tormento infringido al héroe y la condición de trayecto largo y arriesgado construyen la consolidación que actualiza al relato original. Es la dilatada relación de duración y acontecimientos los que precipitan el duelo final y que aseguran luego de una huida accidentada, un regreso victorioso para nuestro fatigado protagonista.

Es también el tiempo el enemigo invisible que sujeta los bordes del camino, el que agita su bandera de llegada y sentencia a nuestro héroe en su intento. Como ese detonador tantas veces utilizado en la saga de Bond donde se literaliza el final como neutralización del conflicto; Como la muerte sorpresiva y violenta de los protagonistas de la mencionada Easy Ryder (Busco mi destino) (Hopper, 1966) que nos habla de héroes vencidos y "sacados" literalmente del camino, como metáfora del recorrido errático y fatal del hombre contemporaneo. 
Un ruta desplazando al drama, la vida como proceso del tránsito lineal hacia un horizonte utópico, y allí el tiempo y el espacio se actualizan y modelizan la angustia existencial del hombre en torno a la ruptura paradigmática de la noción de progreso indefinido bastión de lo moderno.

Cabe preguntarse como se configura este héroe en viaje iniciático. Como se corporiza y proyecta su imagen hacia el mundo que lo observa.

Conforme sus actualizaciones, el cuerpo del héroe sufre mutaciones, duplicaciones y desdoblamientos. En el relato origen, éste aparece como la fuente de juventud y belleza, muestra de poderío y resistencia para enfrentar los avatares prometidos. su recorrido recibe sobre su cuerpo una serie de marcas que, a modo de señales, construirán la idea de peligro y dualidad entre lo humano y lo divino.

\section{Viaje de vuelta o El retorno de Ulises}

Otra de las categorías destacadas en la fundación de relatos de origen es el Viaje de vuelta. Este modelo también se configura como un viaje hacia el reconocimiento, un recorrido hacia la restauración del orden perdido, la re-fundación de la identidad del héroe, tal como se relatara el regreso de Ulises luego de la guerra de Troya a Itaca.

La necesidad de recomponer la identidad se materializa en el retorno, en la vuelta a la casa de la infancia, en definitiva al útero que otrora nos fue negado como estadío permanente. Pero el protagonista de este relato está transformado, alienado, desvastado por los horrores de la guerra, irreconocible frente a su propia familia. Es un hombre que vuelve a repatriarse.

Las estructuras narrativas de estos relatos cinematográficos retoman ese viaje y lo convierten en la razón misma de los films bélicos. ha generado una industria relacionada con éste tópico sin duda alguna.

Asimismo otras cinematografías (latinoamericanas, europeas y asiáticas) lo han hecho desde un cine crítico-expresivo en lugar de un cine espectacular como el correspondiente al llamado MRI (Modelo de Representación Institucional)

La vuelta a casa de los miles de soldados sintetizados en la figura mítica del adalid que intenta recuperar su identidad desmoronada.

Esta identidad debe ser suturada en el camino de regreso y su reconstrucción será a través de la memoria. El relato odiseíco construye el retorno tanto desde un viaje material como de una búsqueda de reparación interior del héroe y su dominio. El protagonista de este relato se actualiza en el cine bélico como un personaje perdido - muchas veces amnésico- que intenta reconstruirse a partir de la mirada de los otros.Volver al hogar luego de la guerra es para él un doble desafío: recuperar el 
orden perdido y, exterminado por su ausencia a la vez que intenta suturar esa herida temporal, y luego restaurar su espíritu que desapareció como saldo de los estigmas bélicos.

En 1976, Scorsese y Schrader coescriben Taxi Driver, el drama de un excombatiente de recorrido errático en un intento de repatriación luego de la guerra de Vietnam. En este caso encuentro en la escena final una puesta en escena que resignifica los horrores sufridos por Travis (Ulises devenido en taxista).

Un Robert De Niro que, luego de innumerables intentos encuentra su peor pesadilla: la imposibilidad de sellar esas heridas y la incapacidad del afuera para contener esa lucha. Entonces nuestro héroe es compulsado a una batalla contra los fantasmas y, errante, despliega una violencia difusa que anula los contornos del género propuesto por Scorsese y tensa así la estructura del film como la idea barthesiana de "salir del cine" (Barthes,1992). Esa idea permite al espectador distanciarse y resignificar esa imagen violenta que se despliega.

De Niro, lejos en el intento de responder al star system de la industria, encarna a un excombatiente que oculta y se oculta durante el film detrás de las marcas que impiden que encuentre un nuevo espacio social. Luego pondrá en imagen esa explosión interior que erupciona durante todo el relato. Así, enfrentándome como espectador al fragmento final me permito la digresión de transcribir el monólogo personal en la penumbra de la sala:

No quiero ver, la mirada se resiste a la seducción del dolor, sin embargo me entrego y padezco. Travis sangra y yo sentada cómodamente en mi butaca, sangro con él.

Me pregunto entonces por que mientras observo esas imágenes con éxtasis hemoglobínico no dejo de percibir que intentan como un latido hacerme despertar. (Sepich, 1998)

En este punto la violencia se extiende a todo el film. Este héroe abandona durante el viaje su inocencia y Scorsese nos prepara solapadamente para la explosión. En la secuencia final, Travis se convierte en justiciero que, victima de la violencia infringida decide pasar a la accion.

Lo destacado del fragmento es que la puesta en escena es extremadamente violenta; Ésto provoca que lo violento se repliegue sobre sí mismo, se refleje, se vea tan insoportable, que genere una parodia de sí misma. Es por ello que no podemos permanecer inertes y extasiados frente al flujo de imágenes. Es que ya sufrimos en silencio empáticamente con Travis, fuimos testigos del desplazamiento de su deseo hacia una violencia difusa, latente $y$, como él, abandonamos la inocencia haciéndonos cargo de ese saber. 
Diría que existe una búsqueda de equilibrio entre esa empatía: la identificación sufriente y un gran distanciamiento. El relato de Taxi Driver logra que nos identifiquemos con ese héroe raído y sin historia, pero al arribar a ese espacio compartido, Scorsese tensa la puesta en escena, propone una lectura reflexiva de los acontecimientos, entonces todos los significantes acuden para revelar lo simbólico.

La duración de los movimientos de cámara, el realente de la banda sonora, los movimientos casi autómatas que adoptan los personajes, no solo desdoblan el género sino que dejan des-hipnotizarnos como espectadores pasivos y lejos de distanciarnos de su sufrimiento, corre ante nosotros el velo de su dolor. Travis se convierte nuevamente en víctima, en sujeto quebrado, en un hombre que no consigue reconstruir su pasado y de esta manera, neutraliza un futuro posible.

La imposibilidad de recrear el origen aparece como el leiv motiv de las actualizaciones odiseicas.

En el contexto de esta realización, Hollywood buscaba un retorno al espectáculo, Scorsese pone en crisis ese renacimiento de los valores americanos que encontraba en el cine un vehículo ideal. Taxi Driver pone de manifiesto la critica al sistema, y resignifica las nociones de recuperación de los criterios americanos como rigidez ideológica, intolerante, al borde de una conducta fascista; y que advierte sobre lo fuera de control, como imposibilidad de tejer nuevamente ese tramado social destruido por la guerra.

Entonces de una forma brutal, el fantasma tan temido es nombrado. Lo violento no es la construcción de la imagen proyectada, sino, la reflexión de esa violencia sobre sí misma.

Frente a una violencia difusa sin enemigos encarnados, no focalizamos hacia un oponente, aparecemos como un ciego blandiendo un cuchillo en una multitud, en un estado de irrealidad digno de la simulación cinematográfica.

Se puede entonces pensar este relato como catártico, como la expiación de la culpa y responsabilidad a través de la observación pasiva de las imágenes, sin embargo, no nos volvemos espectadores encallecidos, por el contrario, la imagen violenta actúa como trampa para la reflexión crítica.

Aquí, la digresión que sostiene el ejemplo de Taxi Driver habla del rol del espectador como elemento sistémico de lo que Eduardo Gruner describe en el prologo de "Nietzsche, Freud, Marx" de Michel Foucault, como " una política de la interpretación” donde tomando palabras de Lawrence "hay que creerle siempre a la narración, nunca al narrador” establece que ninguna estrategia de interpretación, puede alegar ingenuidad. 
Nuestra condición ineludible de interpretes, condenados lectores de imágenes, condiciona la constitución de nuevas subjetividades que podrán luego quizás retotalizarse en consenso para (re) instalar imaginarios sociales, cristalizando las producciones de sentido en una superación colectiva y simbólica.

El intento de analizar el relato de Taxi Driver, permite, de alguna manera, tipificar al héroe modelizador del viaje de vuelta y sus re significaciones ideológicas $\mathrm{y}$ formales.

Hollywood ha sido en gran medida el encargado de replicar a estos héroes odiseico que retornan al hogar y muestran con crudeza las marcas indelebles de la guerra.

En El retorno de Martín Guerre se reformula el papel dramático que desempeña la guerra de Secesión en el imaginario norteamericano. Sin pretensiones, el poema homérico constituye una gran historia moral de expiación, en la que se pone de relieve la inutilidad de la guerra. Aquí también reconozco una marca que se convierte en motivo visual; La imagen de La piedad como resignificación del caído. La imagen replicada una y mil veces del combatiente que sostiene otro cuerpo inerte en un tiempo detenido, un cuerpo adulto sosteniendo otro en un intento de huida hacia un lugar seguro (el hogar), para reconstruir su condición de hombre.

La imagen de La piedad apela a una memoria visual no siempre concebida como presencial sino que supone una concentración de lo trágico, esa suspensión temporal que resume el drama que se produce frente a la experiencia del acunamiento de un hijo adulto abatido. La fuente de esa imagen que sublima la tragedia del acontecimiento contra natura, se actualiza en el cine bélico mascarada en otros cuerpos.

Desde El Nacimiento de una Nación, pasando por Padre Padrone, arribando a films como Rescatando al soldado Ryan o Regreso a Cold Mountain, el motivo visual de la piedad adquiere diversos ropajes.

El espacio como significante cinematográfico reconstruye el regreso material del héroe y justifica el trayecto pero también es metáfora de esa búsqueda de reconocerse $y$ restaurar el orden perdido.

El western como el género que sostiene el retorno a una Itaca polvorienta refunda al Ulises contemporáneo, devenido en cowboy con objetivo de redención.

En la filmografía de Win Wenders también leemos al espacio diegético como metáfora de ese recorrido subjetivo e interior del protagonista.

El espacio de París, Texas se recorre hostil e inconmensurable, estéril e inconquistable, como Travis (otra repetición nominal), que se adentra en su 
angustiado deseo de retorno. La recuperación del hijo como posibilidad de trascendencia, la necesidad de reconocimiento como forma de restaurar su propia subjetividad, y la instauración de un orden preexistente como salvación para un espíritu alienado.

Es destacable el diseño de los espacios en los viajes de vuelta. El cine reconfigura constantemente los códigos del western dilatando o contrayendo los bordes pero describiendo al territorio como errático, hostil, extenso, inabarcable. De esta manera el héroe se inscribe en un ambiente que lo miniaturiza, que lo muestra vulnerable, débil y acentúa así su condición de viajero sin pasado, sin posibilidad de convocar su origen.

La fuente diezmada de este tipo de relato trastoca el tiempo cinematográfico y dilata ese ideal de unidad perseguido por el protagonista. El héroe odiseico se sumerge en una profunda crisis, tanto ideológica como vital, que le produce una mímesis con el espacio caótico del desierto.

Las imágenes producidas por el western clásico del umbral de la casa como metáfora de la visión ordenada y protectora de la sociedad, contrapuesta al afuera árido, despoblado, peligroso, que materializa el caos. Un sujeto que vive a la intemperie, convocado por la "seducción apátrida del vacío” (Balló- Pérez, 1995)

Aquí aparece otro motivo visual vinculado al sujeto en su relación espacial:

El hombre hacia el horizonte, ese lugar utópico que construye la idea dual conclusiva a la vez que imagen de un posible regreso o futuras conquistas en otros espacios.

En la filmografía de John Ford se actualiza este fantasma del héroe que como un extraño vuelve a su tierra y debe, al tiempo que ser reconocido, instaurar el orden anterior a su ausencia.

En general, las estructuras narrativas que responden a este género no le permiten al protagonista permanecer en ese hogar reciclado. De alguna manera éste recupera el sentido nómade de su caminar y se abisma nuevamente al desierto material y simbólico de su existencia. Se presenta como incapaz de confiar en que su retorno será perdurable.

El cuerpo de este héroe se modeliza como un excombatiente devenido en peregrino que dista de ser un cuerpo inaugural. Las marcas no siempre son visibles, pero el abatimiento es condición de este tipo de personaje. Es un cuerpo que no reconoce a la memoria como mapa donde se dibuja. Pero su entorno también trastoca esta percepción de extrañamiento.

Un valioso ejemplo parece ser la escena de París, Texas en donde Travis concurre a un local de comercio sexual para ser reconocido por su esposa. El espacio 
en donde se juega la escena reconfigura la noción de adentro y afuera; De ventanaespejo que puede revelar u ocultar. La noción de ostrenie, instalado por el formalismo ruso, pero reconceptualizado como la incerteza frente al que regresa y requiere ser aceptado. Este reconocimiento es retrasado, como lo fuera el de Penélope a Ulises en el relato original. Ulises al igual que Travis intenta primero reconstruir el vinculo filial para luego presentarse frente a su esposa.

\section{El viaje fundacional o La conquista de Eneas}

La Eneida, el poema de Virgilio instala una nueva categoría de viaje mítico. Un viaje colectivo que proyecta como objeto anhelado la fundación de una nueva patria. Relata la historia protagonizada por un grupo de troyanos supervivientes a la derrota bélica que liderados por el valiente Eneas se encaminan hacia un espacio inaugural.

"En un colectivo que busca una tierra prospera donde fundar su futura patria" (Balló- Pérez, 1995)

Esto reconfigura una noción de nacionalismo que imprime con fuerza el poeta latino. Una concepción integra de identidad aglutinante, que implica un proyecto consensuado hacia el espacio a fundar. El héroe de este relato emerge de las masas y se convierte en la voz de todas las voces, es un líder con visión y que es capaz de replegar sus deseos individuales en pos del éxodo fundacional.

Dentro del relato Eneas es conminado por Dido, profundamente enamorada de él, a permanecer a su lado. Esto hace visible esta tensión que subyace en esta narración origen en relación al deber colectivo y los deseos individuales.

Eneas se ve compulsado a continuar su mandato de líder hacia esa tierra inaugural, es así que Dido presa de un amor profundo con aristas de tragedia decide suicidarse. De esta manera se pone de manifiesto esa "implacable rigidez que suponen las excesivas obligaciones del caudillo con su pueblo” (Balló- Pérez, 1995)

Moisés - configurado como líder fundacional- conduce a una comunidad desamparada y desarraigada hacia un nuevo y glorioso destino. Es ahora el deber y nos los placeres individuales de la gesta odiseica los que constituyen la razón de ser de este héroe.

El espacio del viaje fundacional carga con una connotación extremadamente positiva. Un espacio idealizado por la distancia y la promesa de buenaventura. Moisés inicia su carácter de héroe como descendiente de los héroes grecolatinos nacidos para la acción. Encuentra en el Eneas de Virgilio su modelo estructural.

Durante este viaje, se sucederán conflictos tantos externos (la conquista de pueblos enemigos) e internos ( que se encarnan en la falta de fe hacia el líder) 
El cine norteamericano concentra en el western toda su impronta nacionalista. La conquista del oeste, atravesada por las luchas intestinas, que demoran la instauración de la imagen ideal de patria, son la razón misma del argumento del western clásico. Un pueblo que es liberto y conducido hacia una tierra de oportunidades.

Se produce una relación espacial y conceptual de réplica entre la caravana de colonos parapetados en grandes carromatos polvorientos con el conjunto de naves troyanas en el mar de la Eneida. El tan deseado asentamiento esta signado por un periplo, que a la vez que colectivo, implica al líder la responsabilidad de llevar a buen puerto al grupo.

Es un líder que pertenece a los integrantes que conduce. Llegar a destino tiene una doble condición: el del deber cumplido y el deseo individual cristalizado.

El tema de la conquista se resemantiza a lo largo de la historia. La búsquedas de un espacio como metáfora de identidad y pertenencia se ha traducido en patrones de comportamiento social.

Los tres estadíos diseñados en este tipo de relato, instauran un primer lugar de extranjería, un espacio que la comunidad debe abandonar para construirse en otro lugar. El segundo estadío está relacionado con el tránsito de la conquista, el éxodo comunitario implica vagar por un terreno neutral e inconquistado pero debatido por otros potenciales usurpadores.

La última parada que guarda la epopeya es la instalación en la tierra prometida. Una tierra que -en general- se aleja del ideal proyectado al comienzo del periplo. El asentamiento generado en la utopía colectiva como la respuesta a los pesares de la comunidad, no siempre dejara un saldo positivo.

El género tomado por el cine norteamericano se ha encargado de trazar un mapa de mutaciones del héroe fundacional. Este tipo de líder en los films de la década del 30 poseía un carácter altruista superador de cualquier grieta subjetiva. La condición del héroe representa el deseo colectivo, el colectivo del que emergió

Distanciada por años de significación cinematografía, la ciencia ficción reformula al western clásico, con films como El Planeta de los Simios que configuran un héroe humano frente a la conquista del mundo en manos de los primates, como proyección de un futuro que es revancha de las acciones presentes. Este Moisés futurista se propone encaminar a la población victimizada por los simios hacia la tierra donde vuelvan a ser libres. 


\section{El viaje mesiánico o El retorno de Neo}

Lo que define el relato mesiánico como matriz cultural encuentra su germen en el viaje hacia la tierra prometida. El héroe confecciona sus ropajes en torno al ideal mesiánico donde su rol se construye por medio del autosacrificio: la sangre derramada y redentora.

"El ciclo mesiánico encuentra en los cuatro evangelios del Nuevo Testamento una concreción tan totalizante como difícilmente eludible. La popularidad y el predominio cultural de esos textos los convierte en la referencia fundamental de todos los argumentos alusivos a la visita ansiada de un benefactor" (Balló- Pérez, 1995)

El origen de este héroe está casi exclusivamente vinculado a un niño abandonado, perseguido por el poder establecido, recogido y educado por padres adoptivos que alejado de la comunidad original genera en éste la conciencia errática de su identidad.

Ya adulto, le es revelado a nuestro Mesías su condición de líder y repatriado a su espacio de nacimiento, donde se inscribe en lo que la profecía dicta: Convertirse en líder que libera a la comunidad oprimida y posee la condición sobrenatural que lo protege y le permite captar adeptos.

Luego de la restauración de ese espacio material y conceptual, la muerte del Mesías aparece como función redentora, entendida como "un sacrificio de alcance universal” (Balló- Pérez, 1995)

La inmolación de nuestro héroe le permite recuperar su carácter sagrado, y partir con la promesa de un reencuentro para con sus fieles como instauración de un ciclo abierto.

En la historia del cine, este relato de origen ha adquirido sus más variadas formulaciones. Tanto en sus intentos reconstructivos como en sus manifestaciones más re elaboradas.

La recuperación del relato mesiánico como viaje construye un espacio diegético que se emparenta con la peregrinación religiosa. El caminar de los fieles detrás de un líder capaz de guiarlos a un nuevo orden de las cosas y a un lugar de pertenencia, es el argumento que atravesó la mayor parte de los géneros y registros dramáticos.

La idea de sagrado de la imagen del Mesías produce un distanciamiento no solo en los adoradores del relato original sino en el público cinematográfico.

Lo sacro de Jesús, da como resultado en el orden argumental la necesidad de correr al sujeto enunciador hacia otro personaje con el que resulte mas factible la identificación. 
Por ejemplo en Jesucristo Superstar, la opera- rock llevada al cine por Jewison en 1973, los auténticos protagonistas son Maria Magdalena y Judas, encarnando la confrontación en torno a Jesús.

En la Ultima tentación de Cristo, por el contrario se instala a Jesús como sujeto de la enunciación en una suerte de soliloquio frente a la duda de ser realmente el hijo de Dios. No solo eso sino que hacia el desenlace Cristo se sumerge en un inesperado sueno, e imagina su vida de haberse sometido a la tentación de la normalidad. Es así que en la afilada pluma de Scorsese, Jesús se convierte en hacedor de sus actos y no en mero sujeto sacralizado.

Las reescrituras del relato original en este caso, se ejecutan desde la visión misma del héroe en su mandato y hasta en su dolor, así se releva a un segundo plano la comunidad.

La lista de Schindler, el film de Steven Spielberg, pone de manifiesto esta tensión argumental. El director indaga el rostro del Mesías como salvador; la misión de liberar de la muerte en los campos de exterminio nazi y por último, el perfil de una comunidad violentada. El relato mesiánico pivotea entre estos dos polos: el del héroe y el de la comunidad.

En otras encarnaciones de la figura mesiánica aparece Neo, el salvador elegido en la saga The Matrix para revelar los secretos del universo y guiar al pueblo hacia una felicidad incontrastable. El desconoce su condición de Mesías y allí es donde los polos de este tipo de relatos se ponen en tensión, es la comunidad la que le entrega el cetro de líder y deposita su confianza en la misión.

En otra línea argumental, los films de héroes enmascarados también estructuran sus cimientos en el relato mesiánico. Héroes como Robin Hood, El Zorro y otros que responden al western en alguno de sus postulados donde comparten esa condición de lideres involuntarios frente a una comunidad oprimida o esclavizada.

La ciencia ficción ha recuperado el argumento del viaje mesiánico. El caso de Superman, tanto en su versión de comic como cinematográfica, es emblema de este tipo de héroe. Es condición excluyente del líder salvar a una comunidad sin el derecho de permanecer en ella. Como un extranjero que llega a instalar un nuevo sistema de valores y vuelve al camino después de libertar a su pueblo.

\section{El viaje laberíntico o El castillo de Frank}

Un hombre solo, réplica del hombre común sometido a una estructura inaprensible, opaca e inmóvil, ha dado nacimiento al recorrido que propone el espacio del laberinto. 
El relato encuentra su origen en El castillo, un hombre K, bautismo que habla de su condición de ser no diferencial, corriente. La estructura burocrática sirve como trampa significante para visualizar al enemigo de este tipo de héroe. encarnación del sistema de estructura invisible, que oprime y somete al sujeto es retomada por la cinematografía en numerosos argumentos.

El relato origen de El castillo (Kafka, 1926) se completa con El proceso que según el propio autor no cuenta el intento del hombre por acceder al poder, sino el intento del poder para absorber y anular al hombre. Desde esta premisa parte el héroe del viaje laberíntico. Donde su carácter de universal da como resultante un poder que se eclipsa para el hombre al tiempo que al sujeto se le hace imposible la huida de la mirada y efectos del poder.

Como la ventana-espejo, objeto reutilizado en los argumentos policiales, que emula al interrogatorio, y donde el individuo es visto en totalidad pero le es velada la posibilidad de confrontar con esas miradas voyeuristas.

Este tipo de relato, sublima ese poder a través del espacio. Produce así un desplazamiento del significante a la estructura material del espacio y de esta manera posiciona al héroe en su carácter indefenso. En tanto que el diseño espacial del laberinto construye la espiral caótica del recorrido. En el laberinto se torna dificultoso acceder al orden. El caos del transito esta dado por esa igualación y repetición de la unidad espacial. La escalera que imposibilita tener una clara dimensión de direccionalidad, también se ha convertido en un motivo visual recuperado por la cinematografía.

Las escaleras suponen una conexión, dos espacios separados por esa estructura de caracol. Esta conexión implica un desconocimiento, un estado desorientado del visitante y por supuesto instala la noción de misterio. Una carretera sin principio ni fin.

El tiempo en el laberinto se presenta también alterado. El retraso en el recorrido signado por las intervenciones invisibles del sistema, se suspende en una temporalidad onírica.

El proceso, obra traspuesta en film por Orson Welles, narra el drama siniestro de un sujeto sobrevolado por un sistema opresor y con fines de exterminio.

Como señalara anteriormente, el rol que juega la burocracia y las intercomunicaciones operan en este tipo de relato con comodidad. Brazil, el film de Terry Gillian, genera la narración ubicando al oponente como esa estructura gris y omnipresente del sistema burocrático. La sátira y la ironía desplegada por el director en torno a las citas permanentes que construyera Charles Chaplin en relación al 
advenimiento de una sociedad industrial. El sujeto como número miniaturizado. Este argumento sostiene constitutivamente la forma contemporánea del no-sentido.

El recorrido que otrora fue lineal, o implicaba la conquista de un espacio utópico se convierte en este relato en un andar errático y sin objetivo; El sujeto se mueve con la excusa de evitar la opresión del sistema. Es el sistema el verdadero actante que lleva adelante la acción. Pero nuestro héroe del laberinto es el otro polo que construye el sentido narrativo. La existencia de un individuo, aunque modélico del colectivo elevado a la categoría de personaje, es la razón misma de la relación especular producida por la identificación.

La alienación del individuo moderno y la instalación de la desjerarquía que cimienta la posmodernidad, reconfigura un héroe entregado al éxtasis de la desorientación y la cruz del deambular permanente sin una eventual liberación.

Este orden generado por la estructura kafkiana es percibida como amenaza. El terror de dominio y pulverización de las subjetividades es la razón de la existencia del sistema. La clonación, la duplicación a iguales neutraliza al hombre distinto del hombre, anula la otredad como constitutiva del ser.

Los espacios de la burocracia desplazan este concepto a imagen. El entorno opaco, velado, hombres como máquinas. Autómatas repetidores de un discurso hegemónico que resulta ser la sutura que liga este universo.

La manera que adquiere la narrativa que responde a lo laberíntico, reemplaza las peripecias del viaje de ida con el azaroso e implacable tablero diseñado por el poder dominante. construirse como un enemigo en sombras, el drama del héroe aparece disfrazado de conflicto interno. La lucha del héroe por permanecer integro y no pulverizarse en la nebulosa del sistema.

El tema de la extranjería se recupera en este relato, no ya como un espacio ajeno, sino como la condición misma del individuo y su entorno. No hay posibilidad de pertenencia, hay una neutralizada visión del hogar como espejo que permite la unicidad. En este contexto, el sujeto se sume en un aislamiento casi metafísico. Los estadíos de su viaje caotizados por el diseño voluntario del sistema, lo distancian de otros posibles habitantes replicantes/cados, en otra instancia del recorrido.

El cine latinoamericano acuno este tipo de relatos. Quizás en la década del 60’ alcanzó su máximo esplendor. Films como La muerte de un burócrata (Gutierrez Alea, 1966), un film emblemático de la cinematografía cubana, instalan al Estado como el enemigo numero uno del individuo. La ineficiencia como la condición fundante del poder burocrático.

Es quizás La naranja mecánica (Kubrick, 1971) un hito en personificar al poder como el sometimiento del sujeto en manos de las instituciones educativas. 
The Truman Show (Weir, 1998) en cambio, perpetra este relato trocando al gigante invisible por el rol de los medios masivos de comunicación.

Truman es concebido literalmente como un producto televisivo. Todo el mundo vivido por personaje es pura maqueta. Todas las fisuras están neutralizadas por el diseño de un "productor" que desde su atalaya controla y construye la existencia de su Pinocho.

Truman no ingresa al laberinto hasta que puede identificar una grieta en el sistema. Su visión subjetiva anestesiada por voluntad del Padre, despierta para atravesar el laberinto del no-sentido de su existencia. Es que cuestionar el origen supone una crisis, una sublevación de las formas conocidas que se presentan ante nosotros como orgánicas, de una construcción invisible.

Truman es aquel que despierta y frente al pecado de la imaginación es perseguido por el poder. El salirse de los marcos del discurso hegemónico y autoritario implica un enfrentamiento con un saldo de lucha que dista del happy end hollywoodense. La indiferencia se muestra como un rasgo sobresaliente de este viaje.

La ciencia ficción desplaza esta característica presentando un escenario fatalista. Nuevos totalitarismos relacionados con la serializacion del individuo, lo tecnificado leído como deshumanización. La claustrofobia propia del encierro involuntario es carácter original del visitante del laberinto.

Truffaut traspone la novela de Bradbury, Fahrenheit 451, en un intento de viaje laberíntico en una sociedad signada por la sospecha y el estado policial de vigilancia.

\subsection{El héroe como engranaje}

Como se ha mencionado anteriormente, los procesos de industralización han encontrado en el cine un desplazamiento critico en numerosas ocasiones. En 1936, Charles Chaplin enunciaba en sus Tiempos Modernos, la problemática de la subjetividad en una sociedad masificada.

El fantasma nombrado por el genio relaciona al cuerpo con el objeto. La cosificación del sujeto que es sometido a una maquinización absoluta, evidencia la cosmovisión de la sociedad tecnológica.

"la suspensión de la individualidad en nombre de una uniformizacion productiva y la tiranía horaria” (Balló- Pérez, 1995) son la cara de la misma moneda que diez años antes había planteado Fritz Lang en Metrópolis.

Para profundizar el análisis del viaje laberíntico como principio de la inaccesibilidad a una instancia superadora, me sitúo en el problema de la enunciación, como marco para una nueva digresión con miras a extender la mirada 
hacia el lenguaje cinematográfico y sus manifestaciones narrativas y estilísticas. Mientras que la percepción poética pone de manifiesto una visión del objeto, tratando al mismo tiempo de anular el a priori, generar la singularización, y descontextualiza al objeto. En otra instancia, la percepción se torna polisémica.

A partir de éstos procedimientos formales, es que se observan los ritmos prosaicos y poéticos en la literatura. Los primeros podrían ejemplificarse con los cantos de trabajo (generadores de automatismo en el lenguaje haciéndo las veces de loop de la modernidad) Los ritmos poéticos son los que aparecen con un lenguaje irreductible, produciendo el fenómeno de extrañamiento. Las funciones dominantes y las subordinadas, se entrecruzan, generando un nuevo orden evolutivo de la literatura.

Michelangelo Antonioni, director influido por la literatura existencialista y la idea de narración sin progreso, filma en 1966 Blow-Up, trasponiendo un cuento de Julio Cortazar: Las babas del Diablo. El tema se presentifica como la crisis generada por Cortázar en torno al rol del narrador. Este orden del sintagma -que es violentado por el escritor- sitúa al lector en un lugar similar al que lo coloca Antonioni en su film. Una incomodidad, que impulsa -dado el corrimiento del rol del narrador- al lector (espectador) a generar la competencia que le permite acceder al razonamiento interno de la obra, que en éste caso no responde a esta relación sintagmática (de sucesos o de personajes) que respondería a un verosímil al que accederíamos sin mayores esfuerzos.

El cuestionamiento del orden sintáctico, del que es preso Cortázar pone en crisis también el lugar y la diversidad de narradores, pues se altera no sólo el rol de éste sino las distintas jerarquías entre todos.

Asimismo, se alteran las relaciones temporales, que están fracturadas por diversos mecanismos, impidiendo anclar, en un narrador único, ni logramos generar un orden cronológico de acontecimientos.

En éste punto no puedo dejar escapar las dos temporalidades que se juegan en el relato, por un lado el de la cosa narrada y por el otro la que se desprende del acto narrativo en sí. Las marcas o deícticos que constituyen al anclaje de un enunciador, respondiendo al lugar y la temporalidad de éste, es puesta en jaque, dentro del mismo texto, que no permite contextualizarlo. transposición, relaciona estos elementos en función de la gramática propia de cada lenguaje.

La noción de transposición se define como procedimiento, como el intento de traducción, de pasaje de un sistema a otro, teniendo como base la interpretación de un texto, que permita la generación de uno nuevo, podríamos decir, que a partir de la lectura de un texto, el cuál se convierte en un segundo texto, nos permite generar un tercer texto, producto de la interpretación de ésta lectura. Entonces no 
estaríamos frente a un simple pasaje de un sistema a otro, sino a partir de la instancia de la interpretación. Éste orden que propone el narrador para comenzar a contar, también produce crisis en la construcción de sentido. El quiebre es producido por posibilitar que, al descender por unas escaleras, retrocedamos al domingo del mes pasado (qué pasado? desde qué presente? qué sujeto enunciador lo está narrando?) Los que nos revela el problema de la enunciación. no sólo es la noción de sujeto que enuncia, sino en la construcción de la mirada; tomandola como la que intenta consolidarun concepto de realidad. Ésta no sucede a priori, sino que se construye a partir de la observación, las cosas suceden si se cuentan, los objetos existen si puedo reconocerlos y nombrarlos.

Al desarticular la sintaxis, Cortázar, se desprende de las leyes que ordenan el discurso y reinterpreta los signos y los significantes. Esto genera un sujeto enunciador caotizado, que muta y se corre de las líneas temporales, desplegando un juego de multiplicidades tempo-espaciales, planteando un abanico de simultaneidades.

Éste juego, crea en el lector, la misma incomodidad que instala en el espectador de Blow Up. La idea es ir construyendo la realidad a partir de la mirada de sujeto enunciador; Entonces: Sin ése relato, sin esa reinterpretación de los signos, no existe nada ?; Pues al no haber una realidad a priori, todas las construcciones nos las da el discurso.

La realidad se constituye a partir de la percepción y de las interpretaciones.

Decía Foucault:

La muerte de la interpretación consiste en creer que hay signos, signos que existen originariamente, primariamente, realmente, como señales coherentes, pertinentes y sistemáticas. La vida de la interpretación consiste, al contrario, en creer que no haya sino interpretaciones (Foucault,1995)

Podría decir entonces que las fracturas en la línea temporal y los cambios de sujeto enunciador, que se ven en Las babas..., se reinterpretan en la obra de Antonioni, como cambios en el raccord de movimiento, saltos de eje, elipsis temporales que no permiten la reconstrucción de la metonimia conceptual.

Estas marcas que aparecen como estructurales en el texto de Cortázar, también lo son en el film de Antonioni.

Podríamos decir que la materia de estudio de ambos textos es precisamente la noción de sujeto narrador y de la ruptura, tanto de la línea del sintagma literario, como del raccord y la secuencia cronológica de los acontecimientos en el relato cinematográfico. Ésta crisis involucra, como era de esperar, la construcción de sentido. ambos textos, el lector-espectador, debe producir sentido, a partir de las 
marcas que los autores les ofrecen. La materialización de estas tensiones confecciona al héroe en tanto cuerpo diferido, retrasado, modelizado por los designios mismos de la estructura de las formas. Esta gramática opera como espejo del poder en la narración origen. Ese poder que, opaco, se filtra y posiciona en lo alto de un olimpo monolítico.

Para ejemplificar más claramente ésta noción de crisis en ambos sistemas, tomo al punto de vista como elemento de análisis.

En el comienzo del film, observamos con la mirada inocente de espectador, una serie de acontecimientos que parecen ser próximos espacial y temporalmente, pero no podemos identificar al protagonista, como sujeto enunciador. Lo mismo nos sucede al leer el texto de Cortázar, dónde nos resulta complejo anclar en la figura de un único narrador. Lo que hace entonces es revelar la ilusión de uno omnipresente, en el que propone un corrimiento permanente. Nos dificulta la idea de un anclaje temporal, dónde el aquí y ahora de la instancia de lectura produce un cruce con las distintas temporalidades que se juegan dentro del texto.

En el comienzo del cuento, hay una declaración de principios, respecto al rol del narrador, del contar y del hacer contando. El texto plantea la propia reversibilidad. El ejemplo siguiente permite visualizar este concepto:

... ya que vamos a contarlo, pongamos un poco de orden, bajemos por la escalera de ésta casa hasta el domingo siete de noviembre, justo un mes atrás. Uno baja cinco pisos y ya está en el domingo.(Córtazar, 1959)

Esta pulverización de las coordenadas espacio- tiempo, construye un personaje escéptico, que duda acerca de su percepción de los sucesos, y lo inhabilita para concretar el objetivo, difuso frente a un recorrido que no encuentra referentes.

Si no hay más que dudas, es imposible generar la idea de verdad. La anarquía propuesta por estos narradores quiebra con las certezas del discurso hegemónico.

\section{Desacelerando el motor (de búsqueda) o a modo de Conclusión}

Luego de este recorrido a modo de reflexión -no concluyente- puedo establecer algunos paralelos entre los conceptos volcados en el ensayo y su carácter material como objeto creado. La idea de lo original y lo nuevo signa todos los yacimientos de la cultura.

El cine con su particular gramática ha reconstruído una y mil veces esos relatos y de esta manera no solo actualiza el origen sino que en cada intento se acerca más y más a él. Señalara Borges: Hay que rastrear lo mítico en las actualizaciones más contemporáneas, más cercanas a nuestra experiencia vital. 
En el relato audiovisual todos los significantes aparecen subordinados a la construcción de sentido, allí donde los viajes parecen funcionar como grandes espejos (a veces deformantes, otras de aumento) del viaje en el que convertimos nuestra(s) vida(s). El cine construye una visión superadora de la humanidad, nos "abuena”, nos perdona (mos) sublimando en la imagen especular generada en la penumbra de la sala todos los pesares y conflictos presenciales o temidos de la vida. Pero esta aventura, como en el relato mítico, no es siempre individual.

Qué viaje fundacional cinematográfico es más verosímil que el éxodo de jóvenes latinoamericanos, reconstruyendo el reverso del viaje que otrora avistaron sus abuelos. La nueva fundación re-significa a la tierra prometida con la promesa de un espacio reconciliado con la dignidad. Un viaje colectivo e individual al mismo tiempo. Lo fundacional como problemática generacional y lo singular como la recuperación de una visión positivista de futuro utópico. Un renacimiento propio de una profunda crisis paradigmática. Las grietas en la posmodernidad, recuperan, en un intento desesperado, alguno de los valores descartados de la modernidad.

Qué viaje mesiánico supera los conceptos de extranjería, de lo foráneo que retorna a conquistar espacios con la nueva idea de única nación global.

En la era de la información, qué sistema más omnipresente y funcional a la vigilancia y control suponen las estructuras hegemónicas de comunicación. Un laberinto atractivo, sin jerarquías aparentes, donde el sujeto actual se convierte en acorpóreo. La concepción de una renovada pitagorización del mundo. El laberinto replica constantemente en la subjetividad y en los procesos colectivos. formas de evasión individuales de una sociedad que no contiene a sus integrantes, y que a modo de viaje de regreso, intenta reestablecer la unidad perdida. La reformulación del Estado como valor de eficiencia, retoma una burocracia impersonal ahora diseñada desde una tecnología de soporte intangible y de manipulación remota.

Entonces, cómo escapar a esas modelizaciones que no solo se manifiestan en la creación audiovisual sino que son la estructura invisible que diseña nuestra relato histórico en torno a la sociedad occidental actual.

El realizador argentino Adolfo Aristarain señala que, en su opinión, un cineasta solo realiza un film. No importa cuantas películas haya filmado a lo largo de su carrera, ellas no son más que la de(re)construcción de ese film origen.

En definitiva, el arte, como constructo de la cultura, es el intento inconcluso y en permanente movimiento, que sirve a lo humano para explicar su existencia.

Ese hilo invisible trazado hacia el origen nos vincula en contexto y en la mirada volcada hacia nosotros mismos. Cuanto más alejados de estos relatos creamos mantenernos, más re-actualizados y re-semantizados estarán. 
Alejarnos del mito como raíz de todas las historias construye la paradoja que historiza los vínculos preexistentes. Negar su condición de fuente original, lejos de debilitar el mito, hace latir con fuerza vital a esos héroes transfigurados infinitas veces, a esos espacios testigos de conquistas ancestrales, y fundamentalmente a la reinstalación de la memoria como el eslabón constitutivo que nos sujeta y a la vez, nos liberta.

Sólo vislumbrando los reflejos lejanos del origen es que podemos instalarnos en un presente vívido y reconvertir ese camino con el movimiento que supone un tránsito desparejo -a veces caótico- pero andando esa línea tan permanente como inalcanzable, esa traza que diseña un horizonte particular para cada caminante, un dibujo que solo se percibe en presente, esa utopía que da sentido a nuestros pasos.

\section{Referencias bibliográficas}

Apolonio de Rodas (1496). Edición de Carlos Garcia Gual (1975). El Viaje de los Argonautas. Col. Biblioteca de la Literatura y el Pensamiento Universales. $\mathrm{N}^{\circ}$ 31.Madrid, España. Editora Nacional.

Aumont, Jacques (1985) al.: Estética del cine. Barcelona, Paidós.

Aumont, Jacques y Michel Marie (1990) Análisis del film. Barcelona, Paidós.

Barthes, Roland. (1992) Salir del Cine, De Lo obvio y lo obtuso: Imágenes, gestos, voces. Barcelona. Paidós Comunicación.

Balló, Jordi \& Xavier Pérez (1995) La semilla inmortal. Los argumentos universales en el cine. Barcelona, Anagrama.

Balló, Jordi \& Xavier Pérez (1997) Las imagenes del silencio. Barcelona, Anagrama.

Bordwell, David \& Kristin Thompson (1993) El arte cinematográfico. Una introducción. Barcelona, Paidós.

Calabrese, Omar (1989) La era neobarroca. Madrid, Cátedra.

Carriere, J.C (1997) La película que no se ve. Barcelona. Editorial Paidos.

Cortázar, Julio (1959) Las babas del diablo. En Ceremonias. Buenos Aires. Seix Barral.

Dalí, Salvador (2003) Textos autobiográficos I y II. España. Destino.

Foucault, Michel (1995) Nietzsche, Freud, Marx. Buenos Aires. Ediciones El cielo por asalto.

Kafka, Franz (1926) El castillo. Múnich. Alemania. Kurt Wolff Verlag.

Martin, Marcel (1990) El lenguaje del cine. España. Gedisa.

Morin, Edgar; Adorno, Theodor (1967). La violencia en el cine. De La industria cultural. Buenos Aires. Galerna. 
Truffaut F. (2003) El cine según Hitchcock. España. Alianza Editorial.

Sepich, Julieta (1998) Ensayo sobre Taxi driver. Inédito.

\section{Films citados}

Antonioni, Michelangelo (1966) Blow-Up. Italia- Reino Unido

Chaplin, Charles. (1936) Tiempos modernos. Estados Unidos.

Donner, Richard (1978) Superman. Estados Unidos

Gillian, Terry.(1985) Brazil. Reino Unido.

Griffith, D.W (1915) El Nacimiento de una Nación. Estados Unidos

Gutierrez Alea, Tomás. (1966) La muerte de un burócrata, Cuba.

Hopper, Dennis. (1969) Easy rider. Estados Unidos.

Jewison, Norman (1973) Jesucristo Superstar. Estados Unidos

Kubrick, Stanley. (1968) 2001-Odisea espacial. Reino Unido.

Kubrick, Stanley. (1971) La naranja mecánica. Reino Unido.

Lang, Fritz. (1927) Metrópolis. Alemania

Minghella, Anthony (2003) Regreso a Cold Mountain. Estados Unidos

Schaffner, Franklin J.(1968) El Planeta de los Simios. Estados Unidos

Scorsese, Martin. (1976) Taxi driver. Estados Unidos.

Scorsese, Martin. (1988) Ultima tentación de Cristo. Estados Unidos

Spielberg, Steven. (1984) Indiana Jones y el templo de la perdición. Estados Unidos.

Spielberg, Steven. (1998) Rescatando al soldado Ryan. Estados Unidos

Spielberg, Steven. (1993) La lista de Schindler. Estados Unidos

Taviani, Paolo y Vittorio (1977) Padre Padrone. Italia.

Truffaut, François. (1966) Fahrenheit 451. Reino Unido.

Vigne, Daniel (1982) El retorno de Martin Guerre. Francia

Wachowski, Andy; Wachowski, Larry (1999) The Matrix. Estados Unidos

Weir, Peter. (1998) The Truman Show. Estados Unidos.

Wenders, Win. (1984). Paris, Texas. Alemania.

Welles, Orson. (1962) El proceso. Estados Unidos 